\title{
Exotic flagellates of coastal North Sea waters
}

\author{
Malte Elbrächter \\ Forschungsinstitut Senckenberg, Taxonomische Arbeitsgruppe, \\ Alfred-Wegener-Institut für Polar- und Meeresforschung, Wattenmeerstation Sylt, \\ D-25992 List, Germany
}

\begin{abstract}
Flagellate species have been shown to survive transocean passage by ballast water and the large dinoflagellate Gymnodinium catenatum was introduced from Japanese to Tasmanian waters in this way. Gymnodinium mikimotoi - better known as Gyrodinium aureolum - and Fibrocapsa japonica as well as Alexandrium leeii are good candidates to have been introduced recently. Species which seem to have been introduced recently into the North Sea but apparently are transported from adjacent seas by currents into the region are Gymnodinium chlorophorum and Alexandrium minutum. Species reported as introduced due to misidentifications are Gymnodinium catenatum and Lepidodinium viride. Under other names the species Prorocentrum minimum, Prorocentrum redfieldii, and Heterosigma akashiwo have been known for a long time in the North Sea. The recent reports of three Chattonella species may be either due to introduction or they have been overlooked. The reasons why the introduction of flagellates into coastal North Sea waters is difficult to prove will be discussed.
\end{abstract}

\section{INTRODUCTION}

The long-chain-forming dinoflagellate Gymnodinium catenatum Graham was introduced by ballast water from Japan to Tasmania and also into the coastal waters off north west Spain (for review see Hallegraeff \& Fraga, 1998). Recently, Nehring (1993, 1994, 1995) have reported that this species is now present in the North Sea also (but see below). There is good evidence that some flagellates have been introduced into North Sea coastal waters although it is very difficult to proove this. The reasons are manifold. First of all, taxonomic knowledge of marine flagellates is so restricted that only a few phytoplankton ecologists are able to identify them exactly. On the other hand, taxonomy experts are rarely involved in routine monitoring or long-term phytoplankton investigations. Most flagellates are small and/or have no or only a delicate cell wall. In consequence most of them are so distorted in fixed samples that they cannot be identified or they disappear totally. They can be recognized and identified only when alive. Others have delicate organic scales, these can be identified only with the transmission electron microscope (TEM), e.g., most prasinophytes and the non-calcareous prymnesiophytes. Those which have tiny but more robust scales have to be identified with the scanning electron microscope (SEM), e.g., most cryptophytes and coccolithophorids. Besides ultrastructure also chemical composition, in particular the pigment composition, is now used for characterization of flagellates, e.g., cryptophytes. Culture techniques have been used more frequently only in the last few years. Clonal cultures, now avail- 
able, allowed the additional separation of new taxa by the new techniques of molecular genetic analysis. Thus, many of the flagellates have been described only in the last 10 or 20 years, in many cases from cultures. These are the reasons why there are no adequate identification books on marine flagellates and why only a very few specialists are able to identify flagellates.

A second reason is the inadequate methods used. Algal cultures are not used routinely in phytoplankton monitoring. This is done by counting fixed samples in the inverted microscope (the so-called Utermöhl method) or by using net samples. By the first method only those species which preserve well enough to be identified and which are abundant enough to be found by this method are registrated. Only a variable percentage of the present species, in some cases less than $20 \%$, is covered by the Utermöhl method. Using net samples, also only a fraction of the total species diversity is covered as small species may escape through the meshes.

These difficulties are responsible for there being no adequate long-term studies of marine flagellates to really prove that a flagellate first recorded in an area is an exotic species, introduced by ballast water, aquaculture products or other mechanisms. If a new flagellate in a region appears, the question always arises whether it has been overlooked earlier or misidentified as a common species. In addition, we have to ask, whether the species is only invading the area from other, nearby geographic regions due to changed currents. If the species under question is not found in the neighbouring region this may be once again only a question of lack of knowledge of the flagellates of that region.

Here we report on flagellates we regard as most likely exotic species and separate them from the "pseudo-exotic" species which may be introduced by natural phenomena like currents or first recorded only due to taxonomic misidentifications.

\section{MATERIALS AND METHODS}

Over the last 25 years, net phytoplankton samples taken off List/Sylt in the German Bight, North Sea, have been investigated alive. Ten years ago, Dr. Drebes and the author started a systematic long-term study. Each week (with very few exceptions, e.g, caused by ice covering) samples were taken with a $80-\mu \mathrm{m}$ and a $20-\mu \mathrm{m}$ plankton net at a fixed station (station $1 ; 55^{\circ}, 01.3^{\prime} \mathrm{N} ; 08^{\circ} 27.1^{\prime} \mathrm{E}$ ). Subsamples were inspected in less than $1 \mathrm{~h}$ after collection, first under a dissecting microscope for about $60 \mathrm{~min}$ and later for about 90 min with seawater immersion lenses $50 \times$ at a final magnification of $500 \times$ with a Leitz microscope by one of us. The other followed the investigation on a monitor connected by a video-camera to the microscope. Those organisms we could identify are listed, including their life cycle stages like resting or gamete formation and zygotes. Selected organisms that we could not identify with this method, were isolated and, if growing in culture, investigated by TEM or SEM for exact identification. So far, we have concentrated our studies on diatoms, dinoflagellates, raphidophytes and parasitic flagellates, but have covered cryptophytes, euglenophytes (which are rare), prasinophytes and prymnesiophytes only if species can be identified under the light microscope. 


\section{RESULTS}

\section{Dinoflagellates: exotics}

In the North Sea "Gyrodinium aureolum Hulburt" is the most likely candidate to be an exotic species. The first report of this species dates back to 1966, when it formed a spectacular bloom in Norwegian waters (Braarud \& Heimdahl, 1970). A second bloom occurred in 1968 in the southern German Bight (Hickel et al., 1971). Since then, blooms have been reported regularly in different parts of the North Sea and the Atlantic off England and France. Recent investigations showed that the European bloom-forming species is apparently different from the species Hulburt (1957) originally described from the east coast of North America (Hansen, 1998). Morphological and molecular genetic analyses showed that the European bloom-forming species called Gyrodinium aureolum, Gymnodinium cf. nagasakiense or Gymnodinium nagasakiense by various authors apparently is conspecific with Gymnodinium mikimotoi Miyake \& Kominami ex Oda from Japanese waters (Gentien, 1998; Hansen, 1998).

This species is now a regular component of neritic waters of the North Sea and the Atlantic (Partensky et al., 1991; Gentien, 1998). The blooms of this species may cause fish and invertebrate mortality, not only in fish cages but also in natural habitats (Tangen, 1977). How this species was introduced into European waters is unknown.

Another candidate to be introduced into European waters by ballast waters or aquaculture products is a small species of the genus Alexandrium Halim, a genus in which several toxic species have been reported. Koeman (1997) reports the occurrence of Alexandrium leeii Balech, a dinoflagellate described from waters off Korea. Further reports are from the Gulf of Thailand and the Philippines. Alexandrium leeii is nontoxic and so far has not formed extensive blooms in our waters. Whether it was introduced by ballast water or by aquaculture products or by any other vector is unknown.

\section{Dinoflagellates: pseudo-exotics}

Gymnodinium catenatum Graham is a toxic unarmoured dinoflagellate which produces long chains in the vegetative stage and distinctive reticulate fossilizable resting cysts as hypnozygotes (Anderson et al., 1988). The long chains of vegetative cells are easy to detect in phytoplankton net samples. Therefore there is no doubt that this species was introduced into Tasmanian waters as well as into coastal waters off northwest Spain (Hallegraeff \& Fraga, 1998). Since 1993, Nehring has reported on the occurrence of Gymnodinium catenatum cysts from German coastal waters and succeeded in germinating them (Nehring 1993, 1994, 1995). He speculated that the species, which had been introduced into Spanish waters about 1976, was transported by currents into the North Sea and the Baltic. As shown by Ellegaard et al., (1998) the species of North European waters is not conspecific to the toxic Gymnodinium catenatum, but is a new non-toxic species - Gymnodinium nolleri - which only forms chains of two cells. It is also known from subfossil and fossil sediments in the Skagerrak and Kattegat. Therefore the reports of "Gymnodinium catenatum" in North European waters do not represent an exotic, recently introduced species but a misidentification of a genuine but overlooked component of our waters. 
Gymnodinium chlorophorum Elbrächter \& Schnepf caused a green water discoloration in the German Bight. First, it was identified as "Y 100" (Elbrächter, 1990), a species reported from Japanese waters and later described by Watanabe et al., (1990) as Lepidodinium viride Watanabe et al. Accordingly, it was initially regarded as an exotic species introduced into European waters. Detailed studies showed, however, that the organism from European waters is a new species (Elbrächter \& Schnepf, 1996) and that it had been apparently transported through the English Channel from the coast of France, where it has bloomed for some years (Sournia et al., 1992). Therefore it is not an exotic species; the first suggestions of this were based on misidentification.

A species which might also be transported by currents through the English Channel into the North Sea and Baltic Sea may be the toxic dinoflagellate Alexandrium minutum Halim (Nehring, 1994; Koeman, 1997). This species is known from the Mediterranean Sea and the Atlantic coast off Portugal, Spain and France. However, this tiny species may easily be confused with earlier investigations of the similar Alexandrium tamarense (Lebour) Balech. Alexandrium tamarense was first described from England and is a regular component of German and Danish coastal waters.

For Prorocentrum minimum (Pavillard) Schiller and Prorocentrum redfieldii Bursa, see "Discussion".

\section{Raphidophyceae}

Most certainly, the raphidiophyte Fibrocapsa japonica Toriumi \& Takano is an exotic species. Fibrocapsa japonica was described from Japanese waters in 1973 (Toriumi \& Takano, 1973). It is a large species of up to $35 \mathrm{~m}$ and very characteristic by the presence of several conspicuous mucocysts at the antapical pole. It possesses several small discoid chloroplasts. The species was first recorded in European waters in October 1991 from the Atlantic coast of France (Billard, 1992) and also since 1991 in Dutch coastal waters (Vrieling et al., 1995). Off Sylt, the species was first detected in August 1992 (Elbrächter, 1993, as Chattonella). Since than it has increased in numbers and now it is a regular component of the North Sea plankton, in particular of coastal waters (Rademaker et al., 1998; Elbrächter unpubl.). This species produces neurotoxic substances and it has been shown that this toxin was present in dead seals. The question is open whether the neurotoxins were responsible for killing the seals (Rademaker et al., 1998).

Three other species of raphidophytes might be exotic species; they all belong to the genus Chattonella Biecheler. Since 1991, Chattonella antiqua (Hada) Ono and Chattonella marina (Subrahmanyan) Hara \& Chihara have been found in Dutch waters (Vrieling et al., 1995). Thus, they have been detected in the same year as Fibrocapsa japonica. The first species is described from Japanese waters, the second one from the Indian Ocean. In 1998, Chattonella verruculosa Hara \& Chihara, originally described from Japanese waters, was found in German, Danish and Norwegian coastal waters of the North Sea (Elbrächter, unpublished; Moestrup \& Tangen, personal communication). This is apparently the first record from European waters. Due to identification problems, it is questionable whether these three species are exotics or have been overlooked earlier (see Discussion). Up to now, there is no report on a bloom of these species, and no information exists of whether there is any effect on other components of the ecosystem in European waters. 


\section{DISCUSSION}

\section{Dinoflagellates}

For the bloom-forming Gymnodinium mikimotoi, Gentien (1998) reports some differences between the Japanese and the European populations, which he classifies as subpopulation differentiation. It is not known how many years are required to achieve such differentiations. Therefore the finding of these differences cannot be used to deny the view that Gymnodinium mikimotoi is an exotic species. At the moment, it cannot be decided whether the introduction has been taken place recently or on a larger time scale. This has been demonstrated for a population of the toxic dinoflagellate Alexandrium tamarense from the Orkney Islands, which is more similar to the North American stock of that species than to the European stock (Medlin et al., 1998).

The report of Alexandrium leeii in Dutch coastal waters by Koeman (1997) is a result of intensive phytoplankton monitoring of field samples. There have been no cultures of this species up to now. Therefore it may be possible that detailed investigations on cultures result in the description of another, so far undescribed, Alexandrium species, morphologically very similar to $A$. leeii. The weakness of only field observations has been demonstrated above for the Lepidodinium viride-Gymnodinium chlorophorum species complex.

Recent reports of phytoplankton blooms of Prorocentrum minimum (Kimor et al., 1985) refer to species which must be classified as "pseudo-exotics" as these species are known from our waters under other names. Exuviaella mariae-lebouriae Parke \& Ballantine or Exuviaella apora Schiller (sensu Lebour, 1925) are meanwhile regarded as conspecific with Prorocentrum minimum. "Exuviaella apora" was recorded earlier by Lebour (1925) from waters off Plymouth. The species has a wide geographical range; blooms have been reported from America, Japan, and South Africa.

Prorocentrum redfieldii has been described from the east coast of North America near Woods Hole (Bursa, 1959). Therefore its occurrence in European waters may be regarded as an introduction. It has been reported as bloom forming by Kat (1979) from the Dutch coastal area since 1961, and sometimes it forms blooms also at the North Frisian coast (Elbrächter, 1993). Some authors regard it as a taxonomic synonym of Prorocentrum triestinum Schiller. Under this name it has been reported as bloom forming in many parts of the world. It seems to be distributed worldwide in coastal waters.

\section{Raphidophytes}

Fibrocapsa japonica has many discoid chloroplasts, two flagella and clearly visible mucocysts in the antapical part of the cell. It differs by these features from the chrysophyte genus Chromulina Cienkovski with which it might be confused otherwise. Rarely, we found Chromulina species of similar size, but they have only one or two large chloroplasts, only one flagellum and no conspicuous antapical mucocysts. Thus we are quite sure that we did not overlook this species earlier. We misidentified our first record as a species of Chattonella Biecheler (Elbrächter, 1993) due to our poor taxonomic knowledge of this group at that time. However, photos clearly showed the mucocysts. As the species was detected nearly simultaneously and independently at three European 
coasts, it is not very likely that the species was present earlier in our region. We have been investigating the phytoplankton of the North Sylt Wadden Sea intensively since 1973 (Drebes \& Elbrächter, 1976), and since 1987 by at least weekly sampling. Also, the gradual increase in its abundance supports the view that it was introduced.

Species of another raphidophyte genus, Chattonella Biecheler, are also suspected of being exotics, but this is not so clear. The genus was described from a bloom in the Mediterranean Sea near Algier (Biecheler, 1936). Since then, six new species have been described (Hara et al., 1994). As they are badly preserved in fixed samples they may have been overlooked or misidentified easily as euglenophytes. This might apply also if inspected alive. Thus, in the original description of Chattonella antiqua, Hada (1974) described it as a new member of the Euglenoida. This shows how difficult it is to speculate whether a species represents an introduced species or it is only the first correct identification of an earlier overlooked or misidentified species. In contrast to Fibrocapsa, Chattonella does not possess the characteristic and clearly visible mucocysts. In the North Sea, at least four species have been recorded. Since 1991, Chattonella antiqua and Chattonella marina have been found in Dutch waters (Vrieling et al., 1995). In 1998, Chattonella verruculosa Hara \& Chihara was found in German, Danish and Norwegian coastal waters. This is apparently the first record from European waters. As discussed by Vrieling et al. (1995) the question is open whether these species were overlooked or recently introduced. In sediment samples of the Wadden Sea off Sylt, a species of Chattonella was found which might be a new species. We failed to get it into culture. The first record of such an organism dates back to 1974 when I misidentified it as euglenid, but in 1997 we found it again (Hoppenrath \& Elbrächter, unpublished).

Heterosigma akashiwo (Hada) Hada ex Sournia is the only representative of the third marine planktonic raphidohyte genus present in the North Sea. It causes fish kills in Japanese waters, and for some years also in coastal waters of Australia, New Zealand and elsewhere. Fish kills so far have not been recorded in European waters. This species is suspected of being introduced in some regions. The history of the records of this species demonstrates how difficult it is to judge whether a small flagellate was introduced, overlooked or misidentified. The species was first described by Hada as a new species of the dinoflagellate genus Entomosigma Schiller as E. akashiwo. One year later. Hada described the new "dinoflagellate" genus Heterosigma with the type species Heterosigma inlandica and recognized that his Entomosigma species belongs to the new genus. In several locations of North America a bloom-forming species was identified as Olisthodiscus luteus Carter, a benthic flagellate described by Carter in 1937 from England as "chrysophyte". From the waters off Plymouth, England, a small flagellate was isolated in 1957 and also identified as Olisthodiscus luteus. By ultrastructural investigations it turned out, that Entomosigma akashiwo, Heterosigma iniandica and the species regarded as Olisthodiscus luteus are conspecific, whereas the true Olisthodiscus luteus is a rare benthic flagellate also belonging to the raphidophytes. It took nearly 30 years to show that the apparent "exotic" species Heterosigma akashiwo had been taken into culture from European waters, but misidentified, before it was formally described from Japanese waters. It seems that this species has a worldwide distribution. There is no clear evidence that it has been introduced anywhere. 


\section{LITERATURE CITED}

Anderson, D. M., Jacobsen, D. M., Bravo, I. \& Wrenn, J. H., 1988. The unique, microreticulate cyst of the naked dinoflagellate Gymnodinium catenatum. - J. Phycol. 24, 255-262.

Biecheler, B., 1936. Sur une chloromonadine nouvelle d'eau saumatre Chattonella subsalsa n.gen.n sp. - Arch. Zool. Exp. Gén. 78, 79-83.

Billard, C., 1992. Fibrocapsa japonica (Raphidiophyceae), algue planctonique nouvelle pour les côtes de France. - Cryptogamie, Algol. 23, 225-231.

Braarud, T. \& Heimdahl, B. R., 1970. Brown water on the Norwegian coast in autumn 1966. - Nytt Mag. Bott. 17, 91-97.

Bursa, A., 1959. The genus Prorocentrum Ehrenberg, morphodynamics, protoplasmic structures, and taxonomy. - Can. J. Bot. 37, 1-31.

Drebes, G. \& Elbrächter, M., 1976. A checklist of planktonic diatoms and dinoflagellates from Helgoland and List (Sylt), German Bight. - Bot. Mar. 19, 75-83.

Elbrächter, M., 1990. Dinophyten. In: Biologische Anstalt Helgoland, Jahresbericht 1990. Ed. by Biologische Anstalt Helgoland, 78.

Elbrächter, M., 1993. Dinophyten und marine Flagellaten. In: Biologische Anstalt Helgoland, Jahresbericht 1992. Ed. by Biologische Anstalt Helgoland, 94-95.

Elbrächter, M. \& Schnepf, E., 1996. Gymnodinium chlorophorum, a new, green, bloom-forming dinoflagellate (Gymnodiniales, Dinophyceae) with a vestigial prasinophyte endosymbiont. - Phycologia 35, 381-392.

Ellegaard, M., Kulis, D. M. \& Anderson, D. M., 1998. Cysts of Danish Gymnodinium nolleri Ellegaard et Moestru sp. ined. (Dinophyceae): studies on encystment, excystment and toxicity. J. Plankton Res. 20, 1743-1755.

Gentien, P., 1998. Bloom dynamics and ecophysiology of the Gymnodinium mikimotoi species complex. In: Physiological ecology of harmful algal blooms. Ed. by D. M. Anderson, A. D. Cembella \& G. M. Hallegraeff. Springer, Berlin Heidelberg New York, NATO ASI Series 41. $155-173$.

Hada, Y., 1974. The flagellata examined from polluted water of the Inland Sea, Setonaikai. - Bull. Plankton Soc. Jpn 20, 112-125.

Hallegraeff, G. M. \& Fraga, S., 1998. Bloom dynamics of the toxic dinoflagellate Gymnodinium catenatum, with emphasis on Tasmanian and Spanish coastal waters. In: Physiological ecology of harmful algal blooms. Ed. by D. M. Anderson, A. D. Cembella \& G. M. Hallegraeff. Springer, Berlin Heidelberg New York, NATO ASI Series 41, 59-80.

Hansen, G., 1998. Gyrodinium sp. from Pettaquamscutt River, Rhode Island - the "real" Gyrodinium aureolum Hulburt? - NTNU Vitensk. Mus. Rapp. Bot. Ser. 1998-91, 56-57.

Hara, Y., Doi, K. \& Chihara, M., 1994. Four new species of Chattonella (Raphidophyceae, Chromophyta) from Japan. - Jpn. J. Phycol. 42, 407-420.

Hickel, W., Hagmeier, E. \& Drebes, G., 1971. Gymnodinium blooms in the Helgoland Bight (North Sea) during August, 1968. - Helgoländer wiss. Meeresunters. 22, 401-416.

Kat, M., 1979. The occurrence of Prorocentrum species and coincidental gastrointestinal illness of mussel consumers. In: Toxic dinoflagellate blooms. Ed. by D. L. Taylor \& H. H. Seliger. Elsevier/North Holland, Amsterdam, 215-220

Kimor, B., Moigis, A. G., Dohms, V. \& Stienen, C. 1985. A case of mass occurrence of Prorocentrum minimum in the Kiel Fjord. - Mar. Ecol. Prog. Ser. 27, 209-215.

Koeman, R. P. T., 1997. Identification and enumeration of Alexandrium species in Dutch coastal waters using epifluorescence microscopy. - Phycologia, Suppl. 34, 199.

Lebour, M. V., 1925. The dinoflagellates of Northern Seas. - Marine Biological Association, Plymouth, vii-250.

Medlin, L. K., Lange, M., Wellbrock, U., Donner, G., Elbrächter, M., Hummert, C. \& Luckas B., 1998. Sequence comparisions link toxic European isolates of Alexandrium tamarense from the Orkney Islands to toxic North American Stocks. - Eur. J. Protistol 34, 329-335.

Nehring, S., 1993. Gymnodinium catenatum in German coastal waters. - Harmful Algal News UNESCO IOC Newsl. 7, 1.4 . 
Nehring, S, 1994. Spatial distribution of dinoflagellate resting cysts in recent sediments of Kiel Bight, Germany (Baltic Sea). - Ophelia 39, 137-158.

Nehring, S., 1995. Gymnodinium catenatum Graham (Dinophyceae) in Europe: a growing problem? - J. Plankton Res. 17, 85-102.

Partensky, F., Gentien, P. \& Sournia, A., 1991. Gymnodinium cf. nagasakiense = Gyrodinium cf. aureolum (Dinophycées). In: Le phytoplancton nuisible des còtes de France: de la biologie à la prévention. Ed. by A. Sournia et al. IFREMER Publications, Brest, 63-82.

Rademaker, M., Reckermann, M., Tillmann, U., Tillmann-Maer, A., Colijn, F, Zeevenboom, W. \& Houpt, P., 1998. Fibrocapsa japonica and Heterosigma akashiwo: new observations. - Harmful Algal News 17, 8-10.

Sournia, A., Belin, C., Catherine, M., Erard-Le Denn, E., Fresnel, 3., Pastoureaud, A. \& Soulard, R., 1992. The repetitive and expanding occurrence of a green, bloom-forming dinoflagellate (Dinophyceae) on the coasts of France. - Cryptogamie, Algol. 13,1-13.

Tangen, K., 1977. Blooms of Gyrodinium aureolum (Dinophyceae) in North European waters, accompanied by mortality in marine organisms. - Sarsia 63, 123-133.

Toriumo, S. \& Takano, H., 1973. Fibrocapsa, a new genus of Chloromonadophyceae from Atsumi Bay, Japan. - Bull. Tokai Reg. Fish. Res. Lab. 76, 25-36.

Vrieling, E. G., Koeman, R. P. T., Nagasaki, K., Ishida, Y., Peperzak, L., Gieskes, W. W. C. \& Veldhuis, M., 1995. Chattonella and Fibrocapsa (Raphidophyceae): tirst observation of potentially harmful, red tide organisms in Dutch coastal waters. - Neth. J. Sea Res. 32, 183-191.

Watanabe, M. M. Suda, S., Inouye, I., Sawaguchi, T. \& Chihara, M., 1990. Lepidodinium viride gen. et sp. nov. (Gymnodiniales, Dinophyta), a green dinoflagellate with chlorophyll $a$ and $b$ containing endosymbiont. - J. Phycol. 26, 741-751. 